\title{
The Stratigraphic, Palaeobiogeographic and Phylogenetic Significance of Aquilapollenites
}

\author{
Shreya Mishra1 ${ }^{*}$, Shiva Prakash Kadukothanahalli Nagaraju ${ }^{2,3}$, Mahi Bansal ${ }^{1}$, Vandana Prasad $^{1}$ \\ ${ }^{1}$ Terminal Cretaceous-Cenozoic Ecosystem Laboratory, Birbal Sahni Institute of Palaeosciences, Lucknow, India \\ ${ }^{2}$ Centre for Structural and Functional Genomics, Biology Department, Concordia University, Montreal, Canada \\ ${ }^{3}$ The Nature Conservancy Centre India, New Delhi, Delhi, India \\ Email: *shreyamishra1005@gmail.com
}

How to cite this paper: Mishra, S., Kadukothanahalli Nagaraju, S.P., Bansal, M. and Prasad, V. (2019) The Stratigraphic, Palaeobiogeographic and Phylogenetic Significance of Aquilapollenites. Open Journal of Geology, 9, 597-600.

https://doi.org/10.4236/ojg.2019.910051

Received: August 15, 2019

Accepted: September 20, 2019

Published: September 23, 2019

Copyright (C) 2019 by author(s) and Scientific Research Publishing Inc. This work is licensed under the Creative Commons Attribution International License (CC BY 4.0).

http://creativecommons.org/licenses/by/4.0/

\begin{abstract}
Angiosperm evolved and diversified during Cretaceous. During this course of evolution and radiation, various pollen of uncertain origin had evolved. Aquilapollenites represents the early stock of angiosperms attaining its acme with respect to diversity and dominance during Campanian and Maastrichtian age. It was globally present (except Antarctica) however more dominant in northern hemisphere (Canada, North America, Sakhlain Oblast and China). In India, the Aquilapollenites sp. is present in Maastrichtian aged deposits. The pollen affinity has been associated with Loranthaceae and Santalaceae plant families. Here, a comparative description of all the Aquilapollenites sp. comprising a wide range of morphological diversity has been discussed. The wider morphological diversity and ecological adaptability of Aquilapollenites sp. infer that it is globally significant and warrants a more detailed study.
\end{abstract}

\section{Keywords}

Triprojectate Pollens, Late Cretaceous, Maastrichtian, Paleocene

\section{Introduction}

Aquilapollenites sp. [1] was amended with the advancement in the field of microscopy [2] [3]. Aquilapollenites sp. belongs to a group of Triprojectacites [4]. This group includes angiosperm pollen with three equatorial projections and a polar projection on each side. Aquilapollenites sp. attained its maximum abundance and diversity during Campanian and Maastrichtian [5]. It is believed to evolve during the Turonian [6]; there are several pre-Turonian records from northern and southern hemisphere. Records of this pollen extend up to Eocene 
but most are reworked [7].

There is a total of 180 species of Aquilapollenites sp. out of which only twelve occur in Indian sub-continent, restricted to Maastrichtian aged deposits [8]. The pollen is morphologically very diverse and consists of a wide variety of features. The pollen affinity has been discussed in detail by Jarzen [9] and assigned to Loranthaceae and Santalaceae plant family with uncertainty. Here we present the comparative description of morphological variation in the Aquilapollenites sp. along with its stratigraphic, palaeobiogeographic and phylogenetic significance.

\section{Comparative Morphological Description of Aquilapollenites sp.}

Aquilapollenites sp. bears a unique morphology with three equatorial protrusion and one polar protrusion on each side. It constitutes heteropolar, subisopolar to isopolar pollen forms. The size of the polar protrusion varies considerably. Pollen which either have one very small polar projection (less than half of the developed polar projections) or bear only one polar projection have been transferred to the genus Mancicorpus [3]. The number of equatorial projections is 3 4 , oriented either equatorially or meridional. The shape of equatorial protrusion ranges from cylindrical, auriculate to conical. There is a wide difference between the ratio of polar and equatorial protrusion. In few species both protrusions are well developed while in others either of the two is well-developed. In Indian Aquilapollenites sp. forms, polar protrusion is well developed while equatorial protrusions are very small peg like structure [8]. The apertures are 3 to 4 in number and situated either equatorially or meridionally. The most common aperture type of Aquilapollenites sp. is colpi, rarely demicolpi (common in Indian species) and only one species of tricolporate pollen ( $A$. amicus).

There is a wide variety of morphological diversity in the exine ornamentation, supratectal elements and their distribution. Pollen mostly bear reticulate and striatoreticulate ornamentation. However, psilate, punctate, foveolate, retipilate, infrareticulate and granulate also occur in some species. The supratetcal elements mostly consist of acuminate spines with few species having pila, scale or crystal shaped spines. Most of the Indian Aquilapollenites sp. bear striatoreticulate ornamentation and are devoid of supratectal elements. In few species, dimorphism is very common in Aquilapollenites sp. showing different ornamentation on equatorial, polar and central region of the pollen. Sometimes spines only occur at the borders of the colpi extending from one end to the other forming a "Dragon Comb" like structure [10].

\section{Stratigraphic, Palaeobiogeographic and Phylogenetic Significance of Aquilapollenites sp.}

Aquilapollenites sp. represents the early stock of angiosperm. It originated during the Early Cretaceous when the world was represented by one phytogeographical province [11]. The increased tectonic activity during the late Creta- 
ceous resulted in the formation of new continental assembly and changing global precipitation pattern and climate [12]. The angiosperms diversified during this time gave rise to nine phytogeographical provinces [13]. The Aquilapollenites phytogeographical province was majorly restricted to northern hemisphere due to its higher abundance and diversity in this region. However, Aquilapollenites sp. was globally present in the late Cretaceous palynoassemblages except Antarctica. Its affinity has been related to parasitic plants of Loranthaceae and Santalaceae families with uncertainty [9]. Thus, Aquilapollenites sp. holds an interesting history of angiosperm diversification and adaptation which warrants more detailed study. The vast array of data regarding Aquilapollenites sp. needs to be compiled and analyzed using phylogenetic approach to identify its affinity, contribution in angiosperm evolution and palaeobiogeographic distribution.

\section{Acknowledgements}

I (S.M.) gratefully acknowledge Dr. Vandana Prasad, Director, BSIP, Lucknow for permitting us to publish. I am also thankful to Prof. Gang Li and the organizing committee of UNESCO/IUGS/IGCP 6792019 for their help and travel support.

\section{Conflicts of Interest}

The authors declare no conflicts of interest regarding the publication of this paper.

\section{References}

[1] Rouse, G.E. (1957) The Application of a New Nomenclatural Approach to Upper Cretaceous Plant Microfossils from Western Canada. Canadian Journal of Botany, 35, 349-375. https://doi.org/10.1139/b57-032

[2] Funkhouser, W. (1961) Pollen of the Genus Aquilapollenites. Micropaleontology, 7, 193-198. https://doi.org/10.2307/1484278

[3] Srivastava, K. and Rouse, G.E. (1970) Systematic Revision of Aquilapollenites Rouse 1957. Canadian Journal of Botany, 48, 1591-1601. https://doi.org/10.1139/b70-235

[4] Mtchedlishvili, N.D. (1961) Triprojectacites. In: Samoilovitch, S.R. and Mtchedlishvili, N.D., Eds., Pollen and Spores from Western Siberia, Jurassic-Paleocene. Trudy. Vsesojuzn. Neft. Issl. Geological Rass. Institute, 203-299.

[5] Nichols, D.J. (2003) Biodiversity Changes in Cretaceous Palynofloras of Eastern Asia and Western North America. Journal of Asian Earth Sciences, 21, 823-833. https://doi.org/10.1016/S1367-9120(02)00091-3

[6] Zhou, S.F. and Wang, L.Y. (1983) Pollen of Aquilapolles from Rutung of Northern Jiangsu. Acta Paleontologia Sinica, 22, 531-540.

[7] Khan, A.M. and Srivastava, S.K. (2006) The Palaeogeographic Significance of Aquilapollenites Occurrence in Pakistan. Journal of Earth Science, 28, 251-258. https://doi.org/10.1016/j.jseaes.2005.09.011

[8] Samant, B., Mohabey, D.M. and Paudayal, K.N. (2013) Aquilapollenites and Other Triprojectate Pollen from the Late Cretaceous to Early Paleocene Deccan Intertrappean Deposits of India. Palynology, 37, 298-315. 
https://doi.org/10.1080/01916122.2013.787125

[9] Jarzen, D.M. (1977) Aquilapollenites and Some Santalean Genera. Grana, 16, 29-39. https://doi.org/10.1080/00173134.1977.11864637

[10] Hoffmann, C. and Zetter, R. (2007) Upper Cretaceous Pollen Flora from the Vilui Basin, Siberia: Circumpolar and Endemic Aquilapollenites, Mancicorpus and Azonia Species. Grana, 46, 227-249. https://doi.org/10.1080/00173130701763142

[11] Herngreen, G.F.W., Kedves, M., Rovnina, L.V. and Smirnova, A.S.B. (1996) Cretaceous Palynofloral Provinces: A Review. In: Jansonius, J. and McGregor, D.C., Eds., Palynology: Principles and Application, American Association of Stratigraphic Palynologists Foundation, Dallas, 911-1330.

[12] Chaboureau, A.C., Pierre, S., Donnadieu, Y. and Franc, A. (2014) Tectonic-Driven Climate Change and the Diversification of Angiosperms. PNAS, 39, 14066-14070. https://doi.org/10.1073/pnas.1324002111

[13] Vajda, V. and Bercovici, A. (2014) The Global Vegetation Pattern across the Cretaceous-Paleogene Mass Extinction Interval: A Template for Other Extinction Events. Global and Planetary Change, 122, 29-49.

https://doi.org/10.1016/j.gloplacha.2014.07.014 